\title{
MEDIA MUSIK(LAGU) DALAM PEMBELAJARAN BAHASA ARAB TINGKAT MI
}

\author{
Oleh: $\operatorname{Hasan}^{1}$
}

\begin{abstract}
Abstrak
Pemanfaatan musik sebagai media pembelajaran yang menjadikan proses pembelajaran menjadi menyenangkan dan tidak membosankan. Musik dapat menyeimbangkan kecerdasan intelektual dan emosional sehingga akan memberikan hasil yang baik bagi siswa. Selain itu musik juga mempengaruhi kondisi fisiologis. Kondisi fisiologis yang relaks akan membangkitkan semangat siswa dalam mengikuti proses belajar. Relaksasi yang diiringi dengan musik membuat pikiran selalu siap dan mampu untuk lebih berkonsentrasi dalam menerima pelajaran. Jika hal tersebut dipergunakan dalam pembelajaran bahasa Arab di berbagai tingkatan khususnya tingkat MI yang notabene usia mereka adalah usia bermain maka akan menghasilkan sesuatu yang sangat membantu dalam pembelajaran bahasa Arab.
\end{abstract}

Kata Kunci: Musik, Pembelajaran, MI

\section{Pendahuluan}

Metode belajar kebanyakan dilakukan guru secara monoton, sehingga pekerjaan tersebut menjadi pekerjaan yang sangat menjenuhkan baik bagi guru maupun bagi siswa. Selain itu materi yang disampaikan guru sangat sedikit yang bisa diterima oleh siswa, sekitar 25\% - 50\% saja. Hal ini dapat diketahui setelah diadakan kuis atau latihan setelah selesai menyajikan materi pada saat itu juga.

\footnotetext{
${ }^{1}$ Penulis adalah dosen Sekolah Tinggi Ilmu AlQuran (STIQ) Amuntai Kalimantan Selatan.
}

Jurnal Ilmiah Al QALAM, Vol. 9, No. 17, Januari-Juni 2016 
Kondisi ini seharusnya menuntut para guru untuk bisa memikirkan bagaimana cara agar pelajaran bisa diserap 70\% - 90\% sehingga siswa dapat mencapai nilai yang standar. Kenyataannya bukan hanya guru saja yang merasakan kejenuhan. Kebanyakan siswa juga merasakan hal yang sama, bahkan lebih lagi karena bila setiap kali guru menyajikan materi hanya menggunakan satu strategi saja tentunya siswa akan merasa bahwa sekolah itu adalah sesuatu yang harus dihindari, ditambah lagi dengan sikap guru yang senantiasa marah-marah apabila sebagian besar siswa tidak mengerti dan tidak bisa memenuhi standar nilai, di setiap kuis atau latihan.

Situasi seperti ini bisa membuat siswa semakin bingung dan tidak paham terhadap pelajaran. Oleh karena itu diperlukan modifikasi strategi setiap kali pertemuan agar siswa tidak jenuh dan tujuan pelajaran serta standar nilai bisa tercapai sesuai waktu dan kurikulum yang sedang berjalan. Salah satu modifikasi strategi dalam pembelajaran yang dapat dilakukan oleh guru adalah membuat suasana kelas menjadi relaks dan menyenangkan dengan memutar musik ataupun lagu yang sedang populer sehingga siswa terpancing konsentrasinya dan tanpa sadar motorik dan otak mereka mulai bekerja tanpa paksaan.

Mengajar adalah salah satu tugas dari guru, dimana pembelajaran dapat diartikan sebagai kegiatan yang ditujukan untuk membelajarkan siswa. Penelitian menunjukkan bahwa lingkungan sosial atau suasana kelas adalah penentu psikologiutama yang mempengaruhi belajar akademis. Guru bisa menciptakan suasana belajar yang biasa saja atau kelas yang menjadi suatu pengalaman penemuan yang luar biasa. Untuk membangun suasana yang bagus seorang guru harus bisa membangun suasana kelas yang hidup dan relaks sehingga siswa bisa menerima materi dengan baik. 
Organ tubuh yang berperan penting dalam proses pembelajaran adalah otak. Belahan otak kiri memegang peranan penting dalam kegiatan pembelajaran. Kedua belahan otak dikembangkan secara optimal dan seimbang sehingga belajar dapat berjalan secara maksimal. Dalam pembelajaran perlu megharmoniskan kerja otak kanan dan otak kiri siswa dengan menggunakan musik sebagai sebagai media pembelajaran.

Musik salah satu cara untuk merangsang pikiran sehingga siswa dapat menerima materi pembelajaran dengan baik. Musik baik digunakan untuk media pembelajaran karena musik mampu menyeimbangkan antara otak kanan dengan otak kiri, ini berarti menyeimbangkan antara aspek intelektual dengan aspek emosional. Dalam pembelajaran agar proses belajar dapat berjalan dengan baik, harus ada keseimbangan antara otak kanan dan otak kiri, apalagi untuk materi-materi yang membutuhkan konsentrasi tinggi. Selain itu mengapa musik bisa dijadikan media pembelajaran karena musik dapat merangsang kecerdasan.

Para ahli percaya bahwa pelatihan dengan menggunakan musik membentuk jalur baru di dalam otak dan memberi lebih dari pada sekedar hubungan sebab akibat terhadap perkembangan bagian-bagian tertentu dari otak secara jangka panjang. Musik memicu keterkaitan yang lebih besar dari pada yang dapat diberikan oleh stimulus lainnya terhadap belahan otak sebelah kiri dengan yang kanan dan antara bidang-bidang di dalam otak yang bertanggung jawab atas emosi dan ingatan. Dengan menggunakan musik sebagai alat untuk memaksimalkan potensi manusia akan merupakan upaya yang sangat berarti. Karena musik mampu memotivasi dan mendorong partisipasi dalam kegiatan yang nantinya akan membantu meraih tujuan di 
dalam fungsi-fungsi sosial, bahasa dan motorik $^{1}$. Hal ini juga dikatakan dalam tulisan Campbell bahwa mendengarkan musik telah terbukti melambatkan laju denyut jantung, mengaktifkan gelombang-gelombang otak untuk kegiatan berpikir tingkat tinggi dan menciptakan kondisi mental yang positif, santai, mudah menerima yang ideal untuk belajar.

Teori pendidikan terbaru yang dikutip oleh Sari mengatakan otak akan bekerja optimal apabila kedua belahan otak ini dipergunakan secara bersamasama $^{2}$. Hal ini bisa dilihat jika anak belajar dengan hanya memanfaatkan otak kiri yang memiliki fungsi mengolah seputar sains, bisnis dan pendidikan sementara otak kanannya tidak diaktifkan yang seharusnya memiliki fungsi berfikir, perasaan, bosan dan mengantuk. Begitu juga mereka yang hanya memanfaatkan otak kanan tanpa diimbangi dengan pemanfaatan otak kiri, bisa jadi ia akan banyak menyanyi, mengobrol atau menggambar tetapi hanya sedikit ilmu yang bisa masuk ke otaknya. Salah satu cara untuk memadukan fungsi otak kanan dan kiri yaitu menggunakan musik pada saat menghafal pelajaran.

Metodologi Musical Exposure Towards (Pembelajaran dengan memaparkan musik pada anak-anak) yang dikutip oleh Saritelah didukung oleh kajian ilmiah yang mengungkapkan bahwa pemaparan terhadap musik akan meningkatkan proses pembelajaran di dalam pikiran anak-anak. Hal ini didukung pula oleh para ahli yang berkeyakinan bahwa bermusik (mendengarkan atau bermain musik) ternyata dapat memberikan nutrisi, dan suara untuk meningkatkan gerakan, pendengaran dan ekspresi pada anakanak. Dengan bermusik anak-anak juga bisa meningkatkan keterampilan dan

\footnotetext{
${ }^{1}$ Sari, N.R. Musik dan Kecerdasan Otak Bayi. (Bogor : KH. Kharisma Buka Aksara,2005), hal 50.

${ }^{2}$ Sari, N.R. 2005. Musik dan Kecerdasan Otak Bayi, ... hal 45-46.
}

Jurnal Ilmiah Al QALAM, Vol. 9, No. 17, Januari-Juni 2016 
kreativitasnya, serta mengalami peningkatan IQ spasialnya ${ }^{3}$.

Musik yang baik adalah sangat berharga sebagai perangkat pengajaran. Metode pembelajaran yang menyertakan pemaparan musik kepada anak-anak telah menerapkan seni memadukan musik dengan pembelajaran ke tingkat pendidikan yang baru dan lebih tinggi. Hal ini didukung dengan pernyataan De Porter, dkk. yang menyatakan bahwa musik berpengaruh pada guru dan siswa. Sebagai seorang guru, kita dapat menggunakan musik untuk menata suasana hati, mengubah keadaan mental siswa, dan mendukung lingkungan belajar. Musik membantu siswa bekerja lebih baik dalam mengingat lebih banyak, musik merangsang, meremajakan, dan memperkuat belajar, baik secara sadar maupun tidak sadar. Di samping itu kebanyakan siswa memang mencintai musik ${ }^{4}$.

Musik ada sepanjang masa, dimanapun kapanpun musik selalu ada dalam kehidupan. Hal ini disebabkan karena musik dapat memberikan dampak positif bagi pendengarnya. Secara umum, musik menimbulkan vibrasi, vibrasi itu menimbulkan stimulasi pada gendang pendengaran. Stimulasi itu ditransmisikan susunan syaraf syarat pusat (imbic system) di sentral otak yang merupakan gudang ingatan lalu hypothalaus atau kelenjar segala sesuatunya untuk mengaitkan musik dengan respon tertentu.

Seiring bertambahnya media-media pembelajaran baik itu yang manual maupun yang sudah canggih bertambah juga variasi media pembelajaran. Salah satunya adalah media musik. Tidaklah berlebihan jika ada yang menyatakan musik adalah bahasa universal yang dapat dinikmati, digunakan, serta untuk apa saja. Kenapa tidak keuniversalan musik tersebut disinergikan dengan pembelajaran yaitu musik sebagai mediapembelajaran bahasa Arab.

\footnotetext{
${ }^{3}$ Sari, N.R. Musik dan Kecerdasan Otak Bayi, ...hal 49.

${ }^{4}$ De Porter, B. dan Hernacki, Quantum Teaching,(Bandung: Kaifa,2005), hal 73.
}

Jurnal Ilmiah Al QALAM, Vol. 9, No. 17, Januari-Juni 2016 
Pada umumnya musik dan lagu hanya berperan sebagai media hiburan ataupun sekedar selingan pada proses pembelajaran. Padahal bila digunakan dengan maksimal, musik memiliki memfaat yang besar untuk pembelajaran bahasa Arab untuk MI. Karena pada usia tersebut sangat cocok sehingga akan menghasilkan hasil yang bagus dalam pembelajaran.

Ritme serta lirik lagu dapat membantu mengingat kata-kata lebih baik serta dapat memahami pesan lagu yang lebih dalam dan mengingatnya dalam jangka waktu yang lebih lama. Selain lebih mudah mengingat dan memahami mufradat secara lebih efektif, Menyanyikan lagu berbahasa Arab dapat membantu mengembangkan kalam dengan intonasi yang alami. Karena pada dasarnya pemerolehan kata (iktisab al lughah) usia mereka diperoleh melalui pendengaran (istima').

Melihat pembelajaran bahasa Inggris yang semakin bervariasi musik dimanfaatkan sebagian rupa sehingga menjadi media pembelajaran yang sangat bagus. Maka bermunculanlah progam-progam komputer maupun handphone yang didalamnya ada penggunaan musik dalam pembelajaran. Maka tidaklah dikatakan keliru bila dalam pembelajaran bahasa Arab jika musik dimanfaatkan sebagai media pembelajaran.

\section{Musik dalam Islam}

Jika musik itu dalam pandangan Islam itu halal, musik akan menjadi kebaikan apabila dimainkan atau dinikmati. Namun, jika musik dalam pandangan Islam itu haram, musik sudah pasti membawa keburukan, tidak hanya didunia tapi juga di akhirat. Untuk mendapatkan yang memuaskan mengenai musik dalam Islam, kita dapat merujuk kepada nash-nash agama tentang musik. Di antra dalil tentang tersebut adalah

Jurnal Ilmiah Al QALAM, Vol. 9, No. 17, Januari-Juni 2016 
Rasulullah saw bersabda, “ Akan muncul dikalangan umatku nanti beberapa kaum yang menghalalkan zina, sutera, khamar, dan alat-alat musik.” (HR. Bukhari, Ahmad, Abu Daud, Ibnu Majah).

Berdasarkan keterangan tersebut, selintas kita mendapatkan kesimpulan bahwamusik dalam pandangan Islam adalah haram, kalau tidak dikatakan mengutuk dan melaknatnya. Musik dengan berbagai unsur di dalamnya dipersepsikan sebagai kesia-siaan, alat permainan sekaligus jerat-jerat setan, dan jalan menuju kerugian.

Benarkan seperti itu? Jika benar, orang akan segera beranggapan bahwa Islam tidak sesuai dengan fitrah, tidak meyukai keindahan dan hiburan. Bukankah secara fitrah manusia meyukai keindahan dan musik adalah bagian dari keindahan tersebut?

Tentu tidak seperti itu. Islam dalam agama fitrah.Setiap aspek dari ajarannya berisi bimbingan agar manusia bisa berlaku sesuai fitrahnya. Adapun larangan Islam terhadap musik lebih bersifat pencegahan terhadap aspek negatif yang bisa ditimbulkanya, yaitu melalaikannya dalam mengingat Allah dan menyeret manusia ke dalam jerat-jerat setan. Itulah hukum musik dalam pandangan Islam.

Musik dalam pandangan Islam itu adalah budaya yang dalam hal ini Islam ingin membangun budayanya sendiri. Musik dalam Islam dipandang sebagai bagian dari budaya, maka Islam menginginkan musik sebagai intrument khas. Artinya musik dalam pandangan Islam harus berbeda dari nyanyian dan instrument jahiliyah. Tantangan umat Islam yang akan datang salah satunya adalahbagaimana memunculkan musik khas Islam sehingga tidak adalagi perbedaan masalah musik dalam pandangan Islam. 
Agar lebih jelas, untuk menentukan keharaman musik, lagu, atau nyanyian, beserta aneka demensinya, setidaknya ada empat indikator yang dapat kita petimbangkan.

Pertama, apabila syair-syair berisi kata kotor, melenakan, mesum alias porno, pengagungan terhadap berhala dan hawa nafsu, ajakan terhadap kekafiran dan maksiat, syirik atau menduakan Allah, membangga-banggakan diri atau golongan dengan merendahkan orang lain, berisi permusuhan dan pelecehan terhadap nilai-nilai moral.

Kedua, apabila tercampur baur atau /ikhtilat/ antara laki-laki dan perempuan. Ketika terjadi pencampuran antara laki-laki dan perempuan ditakutkan akan dapat membawa fitnah bagi mereka.

Ketiga, musik dalam pandangan Islam haram jika dibawakan oleh penampilan wanita yang berpenampilan seronokalias mengobral aurat, dengan tarian membangkitkan syahwat, dan dengan suara mendesah-desah lagi menggoda. Atau, musik tersebut dibawakan oleh siapa pun bisa laki-laki atau perempuan dengan memakai atribut dan simbol-simbol setan atau orang kafir.

Keempat, bersama musik tersebut dihidangkan aneka makanan atau minuman yang diharamkan, semacam khamar, beserta aneka fasilitas yang memudahkan orang untuk melakukan maksiat.

Dengan demikian, tidak semua musik dalam pandangan Islam itu haram, ada musik tertentu yang dihalalkan agama bahkan berpahala bila kita menikmati atau membuatnya. Musik seperti apa? Itulah musik yang 
menjadikan kita ingat kepada Allah, taat kepada-Nya, musik sebagai tanda syukur, dan membawa kebaikan bagi orang banyak. ${ }^{5}$

\section{Musik Kunci Kecerdasan}

Bangsa yang terkenal dengan kecerdasannya adalah bangsa Yahudi. Kecerdasan mereka bukanlah faktor genetik/turunan tetapi melainkan kecerdasan yang diperoleh dengan usaha yang luar biasa. Salah satu usaha untuk menciptakan kecerdasan mereka adalah musik.

Musik dikalangan yahudi merupakan sebuah keharusan yang selalu dimilikiseorang bangsa Yahudi sejak kecil bahkan mereka malu jika tidak bisa memainkan alat musik karena mayoritas anak Yahudi bisa memainkannya. Kenapa musik berhubungan dengan kecerdasan? Jawabnya adalah ternyata bermain musik sangat berpengaruh dengan perkembangan kecerdasan otak manusia. Tampaknya orang-orang Yahudi telah mengetahui sejak lama bahwa bermain musik dan memahami not musik dapat meningkatkan IQ (Intelligent Quotient/ kecerdasan) seorang anak. Ini yang barangkali tidak disadari oleh bangsa-bangsa lain selain Yahudi. Kalaupun sadar kesadaran itu datangnya terlambat. ${ }^{6}$

Dalam teori kedokteran pun, lantunan musik berpengaruh besar terhadap pembentukan kecerdasan otak anak serta berpengaruh terhadap kepandaian anak dalam bersosialisasi. Pemahaman orang Yahudi ini selaras

\footnotetext{
${ }^{5}$ Musik dalam pandangan Islam: Halal atau Haram http://www.anneahira.com/musik-dalam-pandangan-Islam. Diakses pada tanggal 17 Juni 2014.

${ }^{6}$ Abdul Waid, Menguak Rahasia Cara Belajar Orang Yahudi,(Yogyakarta: Diva Press, 2012) Cet V, hal. 83.
}

Jurnal Ilmiah Al QALAM, Vol. 9, No. 17, Januari-Juni 2016 
dengan hasil penelitian banyak pakar musik maupun pendidik yang menemukan efek positif dari beberapa jenis musik. ${ }^{7}$

Ketika musik telah dipahami sebagai cara untuk meningkatkan kecerdasan seseorang, maka tidaklah salah satu musik jika musik disinergikan dalam sebuah pembelajaran.

\section{Musik Dalam Pembelajaran}

Musik adalah pantulan dunia di sekitar kita dan juga orang-orang yang membuatnya. Alam semesta tercipta dengan musik alam yang sangat indah. Gemuruh, ombak laut deru angin di gunung, dan rintik hujan merupakan musik alam yang sangat indah dan sudah terbukti, bagaimana pengaruh musik alam itu bagi kehidupan manusia. Pengertian lain mengatakan bahwa musik adalah bunyi yang diterima oleh individu dan berbeda-beda berdasarkan sejarah, lokasi budaya dan selera seseorang.

Dalam kamus Besar Bahasa Indonesia, musik diartikan 1. ilmu atau seni meyusun nada atau suara dalam urutan, kombinasi, dan hubungan temporal untuk menghasilkan komposisi (suara) yang mempuyai kesatuan dan kesinambungan; 2. nada atau suara yang disusun demikian rupa sehingga mengandung irama, lagu, dan kehamonisan (terutama yang menggunakan alat-alat yang dapat menghasilkan bunyi-bunyi itu). Sementara pengikut Pythagoras mendefenisikan musik sebagai persatuan sempurna dari hal-hal yang berlawanan, persatuan dalam keanekaragaman, keserasian dalam pertentangan. Karena musik tidak hanya mengkoordinasikan irama dan mondulasi, tetapi mengatur seluruh sistem; ujungnya adalah menyatukan dan mengkoordinasikan. Musik juga produk pikiran. Menurut parkar elemen vebrasi (fisika dan kosmos) atas frekuensi, bentuk amplitudo dan durasi

\footnotetext{
${ }^{7}$ Abdul Waid, Menguak Rahasia Cara Belajar Orang Yahudi, hal. 85-86.
}

Jurnal Ilmiah Al QALAM, Vol. 9, No. 17, Januari-Juni 2016 
belum menjadi musik bagi manusia sampai semua itu ditransformasikan secara neurologis dan diinterpretasikan melalui otak menjadi picth, warna suara, keras lembut, dan waktu (dalam kerangkal tonal). ${ }^{8}$

Parah ahli percaya bahwa pelatihan dengan menggunakan musik membentuk jalur baru di otak dan memberi lebih dari pada sekedar hubungan sebab akibat terhadap perkembangan bagian-bagian tertentu dari otak secara jangka panjang. Musik memicu keterkaitan yang lebih besar dari pada yang dapat diberikan oleh stimulus lainnya terhadap belahan otak sebelah kiri dengan yang kanan dan di antara bidang-bidang di dalam otak yang bertanggung jawab atas emosi dan ingatan. Dengan musik sebagai alat memaksimalkan potensi manusia akan merupakan upaya yang sangat berarti. Karena musik mampu memotivasi dan mendorong partisipasi dalam kegiatan yang nantinya akan membantu meraih tujuan dalam fungsi- fungsi sosial, bahasa dan motorik. ${ }^{9}$

Teori pendidikan terbaruyang dikutip oleh Sari otak akan bekerja optimal apabilakedua belah otak ini dipergunakan secara bersama-sama. ${ }^{10}$ Hal ini bisa dilihat jika anak belajar dengan hanya memanfaatkan otak kiri yang memiliki fungsi mengola seputar sains, bisnis dan pendidikan sementara otak kanannya tidak diaktifkan yang seharusnya memeiliki fungsi berfikir, perasaan, bosan dan mengantuk. Begitu juga mereka yang hanya memanfaatkan otak kanan tanpa diimbangi pemanfaatan otak kiri, bisa jadi ia akan banyak menyanyi, mengobrol atau menggambar tetapi hanya sedikit ilmu yang bisa masuk ke otaknya. Salah satu cara untuk memadukan fungsi otak kanan dan kiri yaitu menggunakan musik pada saat menghafal pelajaran.

\footnotetext{
${ }^{8}$ Djohan. Psikolog musik.(Yogyarkata: Buku Baik,2005). hal. 24.

${ }^{9}$ Sari, N.R. Musik Dan Kecerdasan Otak Bayi.(Bogor: KH. Kharisma Buka Akasara, 2005), hal. 27.

${ }^{10}$ Sari, N.R. Musik dan kecerdasan Otak Bayi. hal 45.
}

Jurnal Ilmiah Al QALAM, Vol. 9, No. 17, Januari-Juni 2016 
Metodologi Musical Exposure Towards (Pembelajaran dengan memaparkan musik pada anak-anak) yang dikutip oleh Sari, telah didukung oleh kajian ilmiah yang mengungkapkan bahwa pemaparan terhadap musik akan meningkatkan proses pembelajaran dalam pemikiran anak-anak. Hal ini didukung pula oleh para ahli yang berkayakinan bahwa musik(mendengarkan atau bermain musik) ternyata dapat memberikan nutrisi, dan suara untuk meningkatkan gerakan, pendengaran dan ekspresi pada anak-anak. Dengan bermusik anak-anak juga bisa meningkatkan keterampilan dan kreativitasnya, serta mengalami peningkatkan IQ spasialnya. Musik yang baik sangatlah berharga sebagai perangkat pengajaran. Metode pembelajaran yang menyertakan pemaparan musik kepada anak-anak yang telah menerapkan seni memadukan musik dengan pembelajara ke tingkat pendidikan yang baru dan lebih tinggi. Hal ini yang didukung oleh peryataan De Porter, dkk yang meyatakan bahwa musik berpengaruh pada guru dan siswa. Sebagai seorang guru, kita dapat menggunkan musik untuk menata suasana hati, mengubah keadaan mental siswa, dan mendukung lingkungan belajar. Musik membantu siswa bekerja lebih baik dalam mengingat lebih banyak, musik merangsang, meremajakan, dan memperkuat belajar, baik secara sadar maupun tidak sadar. Di samping itu kebanyakan siswa memang mecintai musik.

Selanjutnya para ahli mempercayai bahwa ada hubungan antara musik dengan perkembangan kepribadian fisik dan psikis seseorang. Pengaruh ini hanya tidak dimulai setelah lahir, melainkan anak masih dalam kandungan. Penggunaan musik bagi siswa yang sedang membaca informasi atau materi pelajaran, menyayikan kalimat materi pelajaran yang penting, memutar musik ketika siswa berdiskusi dimana suara musik sama besarnya dengan suara yang dikeluarkan siswa, dan masih banyak lagi cara lain yang bisa dilakukan dengan menggunakan musik untuk pembelajaran. 
Menurut Ortiz, penggunakan musik dalam pembelajaran berguna untuk: 1). Memotivasi anak untuk berlatih, 2). Meningkatkan kepekaan pada tubuh, 3). Mengaktifkan tumbuhnya keterampilan motorik besar, 4). Meningkatkan koordinasi, 5). Mengembangkan rasa percaya diri dan harga diri, 6). Bertindak sebagai katalis untuk improvisasi imajinatif, 7). Memperkenalkan dan mempertahankan stuktur dalam kegiatan-kegiatan yang teratur, 8). Berfungsi sebagai sumber kebahagiaan dan kesenangan, 9). Mendorong terjadinya hubungan sosial, dan 10). Menciptakan lingkungan yang terkendali dimana pengungkapan diri bisa diwujudkan.

Musik juga disebut alat terapi dimana hasil riset menunjukan bahwa musik dapat mengharmoniskan dan mengembangkan semua irama dari badan kita, termasut denyut jantung, kecepatan bernafas, tekanan darah, frekuensi, gelombang otak dan kecepatan respiratory primer, selanjutnya para peneliti juga menemukan bahwa musik dalam menjadi terapi yang baik untuk orang mengalami stress, karena ketika mengalami stress, tubuh memproduksi hormon kortisol dalam jumlah besar, yang dapat melemahkan sistem kekebalan tubuh. Mendengarkan suara musik yang meyenangkan, meningkatkan stsatus dalam keadaan santai mengurangi jumlah kortisol dalam aliran darah dan meningkatkan produksi antibodi spesifik yang memperkuat sisitem kekebalan tubuh dan melindungi badan terhadap infeksi serta penyakit.

Musik dapat mengajarkan pada manusia tentang kebiasaan belajar yang baik, membantunya mengingatkan fakta-fakta dengan mudah baik secara visual dan aural dalam bergerak, mencipta dan berinteraksi dengan kelembutan dan kepekaan dalam mengekspresikan emosi dan membebaskan diri dari stress.

Jurnal Ilmiah Al QALAM, Vol. 9, No. 17, Januari-Juni 2016 
Sebenarnya musik telah digunakan oleh orang Yunani kuno untuk memudahkan mereka menghafal. Namun entah apa sebabnya, selama separuh abad yang silam teknik ini banyak dilupakan di sekolah-sekolah. ${ }^{11}$

\section{Manfaat Penggunaan Musik}

Manfaat penggunaan musik untuk membantu proses pembelajaran yaitu :

1. Musik akan membuat siswa rileks dan mengurangi stress yang akan menghabat pembelajaran;

2. Merangsang kreativitas dan kemampuan berpikir siswa sehingga dapat memporoleh hasil yang lebih baik;

3. Membantu kreativitas dengan membawa otak pada gelombang tertentu;

4. Merangsang minat baca, keterampialn motorik dan perbendaharaan kata;

5. Sangat efektif untuk proses pembelajaran yang melibatkan pikir sadar maupun pikiran bawah sadar.

Untuk menciptakan suasana yang medukung proses belajar, otak perlu mendapat rangsangan yang sesuai, sehingga otak dapat dengan mudah menyerap informasi dan mengerti informasi dan mengembangkan keterampilan berpikir.

Manfaat musik sebenarnya tergantung pada cara kita menggunakannya, kapan dan apa saja jenis musiknya. Berikut penggunaan musik dalam proses pembelajaran.

1. Musik digunakan sebagai pembukaan sehingga pada waktu yang sesuai akan sangat membantu mempengaruhi perhatian siswa di awal proses pembelajara.

${ }^{11}$ Cammpbell, D. Efek Mozart Bagi Anak-Anak. (Jakarta: Gramedia Pustaka Utama,2002), hal. 86.

Jurnal Ilmiah Al QALAM, Vol. 9, No. 17, Januari-Juni 2016 
2. Musik digunakan sebagai pembatas waktu, contonya ketika guru memberikan tugas kepada siswa, maka guru dapat membatasi waktu untuk mengerjakan tugas sampai selesai musik tersebut.

3. Musik digunakan untuk membantu diskusi, saat melakukan diskusi mainkan musik sebagai latar belakang. Pesan music disini adalah untuk menciptakan atmosfir yang mendukung proses diskusi.

4. Musik digunakan untuk membangkitkan semangat dan energi, saat suasana kelas sedang menurun, siswa sudah mulai mengantuk, bosan, atau letih mainkan musik dengan tempo yang tinggi sambil melakukan gerak badan atau brain gym.

5. Musik untuk penutup, jika musik ada sebagai pembuka maka harus ada musik sebagai penutup. Musik ini dimainkan setelah siswa selesai belajar dan bersikap untuk pulang sehinnga pada saat pulang siswa dapat pulang senang dan gembira.

Perbedaan belajar dengan menggunakan musik dengan belajar tanpa musik :

\begin{tabular}{|l|l|}
\hline \multicolumn{1}{|c|}{ Tanpa music } & \multicolumn{1}{|c|}{ Mengunakan musik } \\
\hline $\begin{array}{l}\text { Denyut nadi dan tekanan darah } \\
\text { meningkat sehingga otak menjadi } \\
\text { tegang sulit untuk menerima } \\
\text { materi pelajaran }\end{array}$ & $\begin{array}{l}\text { Deyut nadi dan tekanan darah } \\
\text { rendah sehingga otak menjadi } \\
\text { relaks dan mudah untuk menerima } \\
\text { materi pelajaran. }\end{array}$ \\
\hline $\begin{array}{l}\text { Gelombang otak semakin cepat } \\
\text { sehingga akan mengakibatkan } \\
\text { pesan yang sudah disampaikan ke } \\
\text { otak akan cepat hilang dan tidak } \\
\text { tersimpan ke longthrem memory. }\end{array}$ & selombang otak melambat \\
sehingga siswa akan meyimpan \\
\hline
\end{tabular}

Jurnal Ilmiah Al QALAM, Vol. 9, No. 17, Januari-Juni 2016 


\begin{tabular}{|l|l|}
\hline $\begin{array}{l}\text { Otot-otot menegang, sulit untuk } \\
\text { menerima materi pembelajaran. }\end{array}$ & $\begin{array}{l}\text { Otot-otot relaks, mudah untuk } \\
\text { menerima materi pelajaran. }\end{array}$ \\
\hline
\end{tabular}

\section{Contoh Penggunaan Musik dalam Pembelajaran Bahasa Arab}

Sebagaiman telah dipaparkan diatas banyaknya manfaat musik bila digunakan dalam pembelajaran. Di sekolah TK atau MI, porsi penggunaan masih besar (walaupun di MI semakin berkurang porsinya) banyak sekali musik yang sering diajarkan dengan lirik yang sederhana. Lirik sederhana tersebut diganti dengan kalimat dalam bahasa Arab yang sederhana juga dan sesuai dengan logika mereka. Berikut ini lirik yang digunakan dalam pembelajaran bahasa Arab.

Contoh pertama musik yang sering didengar siswa TK/MI seperti lagu Dua Mata Saya, kemudian diubah menjadi lirik dalam bahasa Arab seperti berikut ini (Lebih baik lagi diiringi dengan instrumen musik yang sesuai).

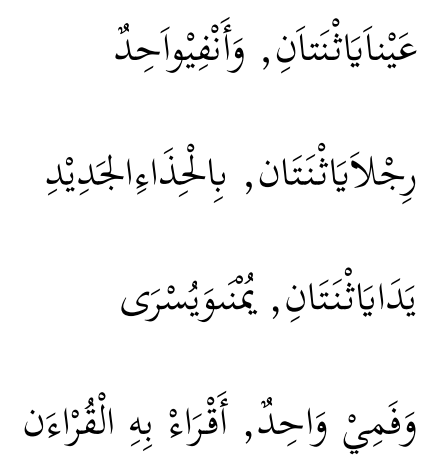

Lirik diatas adalah diambil dari lagu anak-anak berjudul Dua Mata Saya

Dua mata Saya, Hidung saya Satu

Dua kaki saya, pakai sepatu baru

Dua tangan saya, yang kiri dan kanan

Satu mulut saya tidak berhenti membaca Quran

Jurnal Ilmiah Al QALAM, Vol. 9, No. 17, Januari-Juni 2016 
Contoh lagu yang kedua yang sering dinyanyikan anak TK maupun MI adalah lagu tentang Pelangi yang diubah menjadi lafal bahasa Arab yaitu:

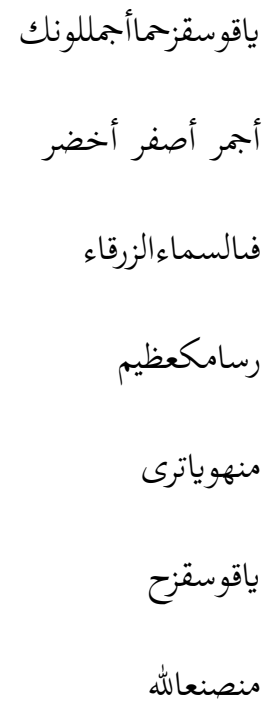

Versi Indonesia

Pelangi pelangi alangkah indahmu

Merah kuning hijau

Di langit yang biru

Pelukismu agung

Siapa gerangan?

Pelangi-pelangi ciptaan Tuhan

Sebenarnya masih banyak lagi contoh-contoh yang lain, baik yang tersebar di internet maupun yang sudah ada di buku pelajaran bahasa Arab siswa seperti buku pelajaran bahasa Arab MI/SD kelas 3 terbitan Erlangga. Hal ini juga sangat dipengaruhi oleh kreatifitas dan inovasi seorang guru dalam menciptakan lirik dalam bahasa Arab serta dipadukan dengan musik yang sering didengar anak.

Jurnal Ilmiah Al QALAM, Vol. 9, No. 17, Januari-Juni 2016 


\section{PENUTUP}

Musik adalah bahasa universal yang selalu sesuai dengan usia, jenis kelamin dan lain sebagainya. Maka tidak mengherankan musik juga dapat digunakan dalam pembelajaran khususnya pembelajaran bahasa Arab. Ketika musik digunakan dalam rangka pembelajaran bahasa Arab maka bertambahlah media pembelajaran.

Dalam hal penggunaan musik dalam pembelajaran bahasa Arab sangat diperlukan kreatifitas dan pengetahuan luas seorang guru dalam menciptakan lirik-lirik pembelajaran bahasa Arab yang sesuai dengan tingkat pendidikan siswa didik.

Diharapkan ketika pembelajaran bahasa Arab dengan menggunakan kreatifitas guru khususnya dalam menggunakan musik sebagai media pembelajaran dan bahkan juga memadukan dengan metode permainan maka siswa pun bersemangat mengikuti pembelajaran dan tentunya hasil dari pembelajaran tersebut sesuai dengan yang diharapkan.

Jurnal Ilmiah Al QALAM, Vol. 9, No. 17, Januari-Juni 2016 


\section{DAFTAR PUSTAKA}

Cambell, D..Efek Mozart Bagi Anak-Anak. Jakarta: Gramedia Pustaka Utama, 2002

Djohan. Psikologi Musik. Yogyakarta: Buku Baik, 2005

Hamdani, Firman dkk, Belajar Bahasa Arab Madrasah Ibtidaiyah Kelas 3, Jakarta: Erlangga, 2008

PSIA STIQ Amuntai, Metode Belajar Bahasa Arab untuk anak SD/MI, makalah, 2014

Sanjaya, Alit Adi. Penggunaan Musik Dalam Pembelajaran di Kelas untuk Menciptakan Kerja Otak yang Harmonis, 2010

Sari, N.R. Musik dan Kecerdasan Otak Bayi. Bogor: KH. Kharisma Buka Aksara, 2005

Waid, Abdul, MenguakRahasia Cara Belajar Orang Yahudi, Yogyakarta: Diva Press, 2012, cet V

\section{Internet}

http://www.anneahira.com/musik-dalam-pandangan-Islam.htm

http://tataitusinta.blogspot.com/2012/06/pemanfaatan-musik-

sebagaimedia.html

http://edukasi.kompasiana.com/2010/12/17/penggunaan-musik-

dalampembelajaran-di-kelas-untuk-menciptakan-kerja-otak-yang-

$\begin{array}{lllll}\text { harmonis/. Diakses } & \text { tanggal } & 16 & \text { Juni } & 2012\end{array}$

Jurnal Ilmiah Al QALAM, Vol. 9, No. 17, Januari-Juni 2016 
Hasan: Media Musik (Lagu) Dalam Pembelajaran Bahasa Arab Tingkat MI 